\title{
Analysis on Proper Application of Body Language in National Dance Teaching
}

\author{
Junping Yang \\ Music and Dance Institute, Beifang University of Nationalities, Ningxia, 750021, China
}

\begin{abstract}
Keywords: National dance teaching, Body language, Function, Proper application
\end{abstract}
\begin{abstract}
With development of China's economy, people's living standards are improved. People paid more and more attention to the pursuit for spiritual world. Under such historical background, dance is widely appreciated by many people. As an important part of dance, national dance also received wide attention. At present, various colleges and universities invested much energy in teaching of national dance, and tried their best to improve the teaching quality of national dance. However, proper application of body language is an effective approach used to improve the teaching quality and national dance. In this paper, the author analyzed proper application of body language in national dance teaching, providing certain guidance to teaching of national dance in China.
\end{abstract}

\section{Introduction}

Proper application of body language can make national dance more infectious and more expressive. In the teaching process, therefore, teachers should utilize the mode of oral instruction. Usually, body language is also used, namely teaching of national dance in which students are guided to express emotions in the dance through certain facial expressions, action and other body languages. Many teachers have recognized the significance of body language in the teaching process of national dance. However, fewer teachers have enough understandings about how to properly apply body language. At first, the author made a simple analysis on features and functions of body language expression. Then, the author proposed relevant methods and measures for proper application of body language in the teaching process of national dance, providing certain reference to Chinese teachers for more reasonable application of body language in national dance teaching.

\section{Features of Body Language Expression}

\section{The feature of movement}

Dance is an art. In the process of dance teaching, teachers should give oral explanation to movements in the dance, and give standard examples for dance movements to students. Through standard demonstration of dance movements, teachers can make students to clearly master essential movements of national dance. Compared with oral instruction, application of body language can improve students' learning interests, and deploy their dance learning initiative. Various happy, dolorous and gentle emotions included in national dance are mainly expressed through certain body movements. The future of movement is an important feature of body language expression.

\section{The feature of accompanying assistance}

In the teaching process of national dance, teachers usually combined body language with oral instruction. To a large extent, body language makes up abstraction, boringness and insufficiency of oral language. Application of body language makes teachers' oral instruction more direct and more expressive. Therefore, body language also presents the feature of accompanying assistance.

\section{The feature of feeling conveying}

Body language combines facial language, body language, look language, sign language and others. Therefore, body language can give proper expression to emotional appeals in the dance. Compared with oral instruction, body language is more vivid. For instance, certain facial expressions are used to convey emotional features of the dance; and certain body languages and movements are used to convey the degrees of emotion in the dance. In the teaching process of relatively complicated national 
dances, proper application of body language can properly convey emotional colors of the dances to the maximum extent ${ }^{[1]}$. In the teaching process, whether teachers have rich expressions, whether their languages are infectious and whether their demonstration actions are standard have great influence on students' inward world. Dance teachers who can properly apply body language can appropriately convey emotions in the dance to students, and effectively improve infection of the dance. The feature of feeling conveying is another feature of body language expression.

\section{The feature of situation}

Besides, body language expression also has the feature of situation. The reason is that the same body language may convey different meanings in different times and sites. For example, teachers will clap their hands while seeing their students doing standard dance movements or having progress when compared with the last class. This movement conveys the meaning of teachers' praise for their students. However, teachers will also clap their hands while collecting students for dance training or arousing students' attention. At this moment, the meaning that teachers want to convey is far more than praise. Therefore, body language in different situations has different meanings. Only when teachers and students are in the same situation, body language can be properly convened.

\section{The feature of consciousness and subconsciousness}

The same as human's inner world, body language also includes consciousness and subconsciousness. In dance teaching process, body language consciously or unintentionally conveyed by teachers will have important influence on students and teaching quality [2]. For example, teachers always praise students' dance with smile, nodding and other conscious body languages, which can greatly improve students' confidence. Usually, teachers use conscious gestures to guide students' dance movements, making their movements more standards. At the same time, some teachers will also unintentionally bring some unhealthy emotions in life into dance teaching classroom. In dance teaching process, inactive emotion, agitation, unconscious impatience for some students with poor comprehension and other similar body languages seriously affect students' dance learning initiative.

\section{Function of Body Language Expression}

\section{Body language plays a role in information communication.}

In the teaching process of national dance, teachers convey certain information through vivid body language. For instance, teachers teach essential movements to students through demonstration. Teachers convey the information of praise and encouragement through nodding and clapping hands. Teachers convey the information of happiness through smile.

\section{Body language plays a role in emotional exchange.}

Teachers use body language to convey emotional information. Students receive such information. Thus, it is unnecessary for oral exchange between students and teachers. For instance, teachers convey their encouragement to students through body language. Students will be confident of themselves after receiving such information of encouragement, so as to make more efforts to learn about dance movements and increase their appreciation for teachers ${ }^{[3]}$. Therefore, body language plays a role in emotional exchange.

\section{Body language plays a role in classroom regulation and control.}

Body language plays a role in regulation and control of dance classroom. For instance, teachers can maintain a smile at any time to create an easy learning environment. For some students who don't carefully learn, listen to teachers or affect other students in class, teachers can attract their attention or stop these students' bad behaviors by giving gestures or expressing serious emotions. Inevitably, students will blundering or disgusted in class. However, these psychologies will be expressed through students' body language. Teachers can utilize encouragement or other body languages to properly adjust students’ bad behaviors by observing students' body languages. 


\section{Proper Application of Body Language in National Dance Teaching}

\section{Utilize standard body language for teaching}

Under normal conditions, facial languages and body languages we use are relatively random, without specific standards or requirements. However, national dance is served as a course. Application of its body language should have strict standard and specifications. For example, teachers' demonstration of dance movements should be based on texts. Any improper modification is not allowed. For the information of encouragement, guidance and others to be expressed, proper body languages should be used for expression, so as to appropriately convey the information to be conveyed by teachers. Out of expectation, some dance teachers want to teach dance movements as much as possible in limited class. Action demonstration is too fast, or it is not standard. To some extent, students cannot understand teachers' demonstration. As a result, students cannot properly master these dance movements, and teaching quality cannot be effectively improved. In the teaching process of national dance, impatience, indignation and other body languages expressed by teachers in class are non-standard and unqualified ones. These body languages should be avoided in dance teaching classroom ${ }^{[4]}$. Particularly, some teachers express indifference and other non-standard emotions in the teaching process of national dance, giving a kind of misconception to students that good or bad performance makes no great difference. Some students even think that the teaching contents are not important. Teachers fail to set a good example for students. As a result, students' dance movements and facial expressions have no certain standards and specifications, thus affecting the teaching quality of national dance.

\section{Lay emphasis on exchange and feedback of body language in class}

In traditional teaching mode, students passively receive what teachers are saying. Teachers are in the dominant position of teaching activities. Teachers lay little emphasis on students' feedback of classroom teaching. This teaching mode seriously affects the improvement to teaching quality. Actually, students are by no means in the passive receiving position of teachers' teaching contents and modes. In the classroom of national dance, students will express happiness, lose, shaking head and other body languages. All these body languages are closely correlated with teachers' teaching. Therefore, it is of great importance for attention to exchange and feedback of body language in the teaching classroom of national dance. In class, teachers need to pay attention to each student' body language at any time, and analyze students' psychological changes, so as to provide assistance to better development of national dance teaching. For example, in the demonstration process of dance movements, teachers pay attention to whether students are fully concentrated on teachers, expressing the behavior of careful watching or shaking head, or whispering to each other. If students' attention is completely attracted by teachers' demonstration, it indicates that the teaching effect is good. If not, teachers should make timely adjustment to these teaching modes or utilize gesture or other body languages to effectively stop students' unhealthy classroom behaviors. In the teaching process of national dance, teachers find that some students lose their interest in national dance or are unwilling to practice dance movements due to insufficient confidence, easiness to get blush or embarrassed or failure to completely master essential knowledge of movement after practice for several times. At this moment, teachers should give timely encouragement and guidance (such as nodding, smile or clapping hands), so as to encourage and praise students, and increase their confidence ${ }^{[5]}$. In short, teachers should pay attention to students' body language at any time in the teaching process of national dance. Moreover, teachers should also exchange and communicate with students through proper body language, so as to improve the teaching quality of national dance.

\section{Avoid bringing some unhealthy body languages into classroom teaching}

Each person will be happy or unhappy. So does a national dance teacher. In case of happy things, teachers will teach dance in a happy and easy mood. Nationally, the teaching quality is good. In case of some unhappy or sad things, however, teachers will be inevitably down in spirits. Unhealthy emotions of national dance teachers will be more or less unconsciously brought into the dance teaching classroom. For instance, some teachers are easy to get angry due to bad mood. At this moment, they are usually too strict for students, affecting the teaching progress. During 
demonstration of dance movements, some teachers are absent in mind, resulting in non-standard demonstration. Under such circumstance, teachers should make timely adjustment to their unhealthy emotions, and maintain a smile on class as much as possible, so as to avoid any impact on students' learning due to their unconsciously unhealthy emotions and not to affect the teaching quality of national dance. For some students in bad performance, their dance movements cannot be standard unless teachers teach them for repeated times. Teachers should not be impatient for these students. Instead, teachers should give patient guidance, encouragement and affirmation, allowing them to feel teachers' care and concern. Teachers' body language is an important part in the teaching process of national dance. Through certain body language, teachers can convey specific information. Students' dance learning attitudes will be always influenced by teachers' body language. Therefore, teachers should avoid unhealthy body languages in the teaching process as much as possible.

\section{Conclusion}

To sum up, body language is of great importance for teaching of national dance. Therefore, teachers should give full play to the functions of body language in information conveying, emotional exchange and classroom regulation \& control by proper application of body language, so as to make national dance teaching more vivid and more infectious, improve students' learning initiative, and make dance teaching activities to yield twice the result with half the effort. Based on a complete discussion on features and functions of body language expression, the author proposed relevant methods used by teachers for proper application of body language in the teaching process of national dance, providing effective reference to national dance teaching in China.

\section{References}

[1] Xiang Lili, Discussion on Aesthetic Extension in National Dance Teaching in Higher Vocational Education, Art and Literature for the Masses, 2010, (2): 197;

[2] Dong Le, Exploration for Optimizing Strategy of China's National Dance Teaching, Northern Music, 2014, (4): 10-11;

[3] Li Ting, Discussion on Several Experiences in National Dance Teaching, Duyuxie, 2012, (56): 176;

[4] Wu Di, Analysis on National Dance Teaching Strategy, Heilongjiang Social Sciences, 2014, (12): 91-91, 95;

[5] Ding Xiaohong, My Opinions on National Dance Teaching, China Education Innovation Herald, 2013, (16): 186. 